\title{
F16-IL2 Fusion Protein
}

National Cancer Institute

\section{Source}

National Cancer Institute. F16-IL2 Fusion Protein. NCI Thesaurus. Code C91395.

An immunocytokine of the human monoclonal antibody fragment F16 (scFv) against the extra-domain $\mathrm{A} 1$ of tenascin-C fused, via a short 5 -amino acid linker, to a recombinant form of the human cytokine interleukin-2 (IL-2) with potential immunostimulating and antineoplastic activities. The monoclonal antibody portion of the F16-IL2 fusion protein binds to tumor cells expressing the tumor associated antigen (TAA) tenascin-C. In turn, the IL-2 moiety of the fusion protein stimulates natural killer (NK) cells, macrophages and neutrophils and induces T-cell antitumor cellular immune responses thereby selectively killing tenascin-C-expressing tumor cells. In addition, F16-IL2 may potentiate the cytotoxicity of other chemotherapeutic agents. Tenascin-C, a glycoprotein of the extracellular matrix, is expressed in many cancer cell types. 